\title{
DIVERSE STRATEGIES IN HUMAN RIGHTS EDUCATION: SHARING EXPERIENCE OF INTRODUCING HUMAN RIGHTS AS UNDERGRADUATE COMMON CORE COURSE IN KENYA
}

\author{
Uchenna Emelonye*
}

\begin{abstract}
The international community emphasized the essence of Human Rights Education in 1995 with the declaration of the UN Decade for Human Rights Education. In 2004, the UN General Assembly unanimously proclaimed the World Programme for Human Rights Education which in 2010-2014 was focussing on introducing human rights in the higher education system. Whilst these UN frameworks have facilitated the incorporation of human rights in higher education through policies, teaching and research, it has not yet led to the elevation of human rights as a common core course for all undergraduate students of universities. On the understanding that a multidisciplinary study of human rights for all undergraduate students has the ability to empower and inspire students as future human rights protectors, promoters and defenders, the United Nations Office of the High Commissioner for Human Rights (OHCHR) collaborated with three pilot universities in Kenya to introduce human rights as a first year, first semester - common core course for all undergraduate students. The methodology was through a three-prong approach commencing with consultations with relevant stakeholders aimed at presenting the initiative for the buy-in of respective pilot universities. These consultations also enabled OHCHR to engage with the leadership of the respective universities for requisite Senate resolutions and approvals. Following the conclusion of stakeholder consultations and endorsement by respective Senate of pilot universities, OHCHR hosted a curriculum development and validation workshops where representatives from academia, the judiciary, police, prosecutors, lawyers, civil society actors, and national human rights institutions provided input on the proposed content of the common core course on human rights. Thereafter, OHCHR in collaboration with the pilot universities conducted a series of substantive and pedagogical capacity building exercises for faculty members
\end{abstract}

\footnotetext{
* Dr., Senior Human Rights Adviser, United Nations Office of the High Commissioner for Human Rights. LL.D (University of Helsinki Finland); LL.M (Central European University Budapest Hungary); LL.M Abia State University Nigeria; LL.B (Abia State University Nigeria); BL (Barrister and Solicitor of the Supreme Court of Nigeria). This paper was presented during the Fifth International Conference on Human Rights Education at the Washington College of Law USA (December 4 - 6, 2014). It is written in a personal capacity and does not represent the views of the United Nations. Research fields: Human Rights, Child and Gender Justice, Rule of Law, Good Governance.
} 
earmarked to teach the course. This unprecedented initiate is commendable and is essential for the promotion, protection and universal respect for and observance of all human rights and fundamental freedoms for all and by all.

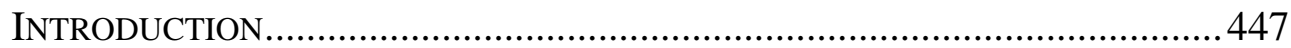

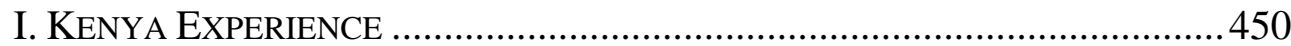

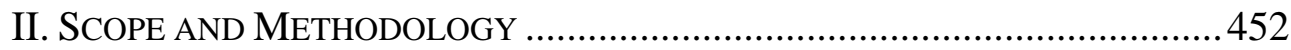

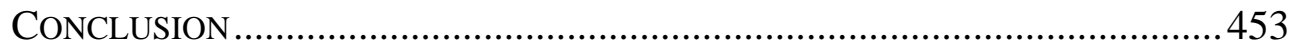

\section{INTRODUCTION}

In 1995, the World Conference on Human Rights in the Vienna Declaration and Programme of Action stipulated that "human rights education, training and public information were essential for the promotion and achievement of stable and harmonious relations among communities and for fostering mutual understanding, tolerance and peace." ${ }^{1}$ Calling on States and institutions to include human rights, humanitarian law, democracy and rule of law as subjects in the curricula of all learning institutions in formal and non-formal settings, the conference recommended the full development of the human personality and the strengthening of respect for human rights and fundamental freedoms through education. ${ }^{2}$

As part of the implementation of the recommendations of the World Conference on Human Rights, the United Nations General Assembly proclaimed the Decade for Human Rights Education beginning on 1 January 1995 and also welcomed the Plan of Action for the Decade contained in the report of the Secretary-General. ${ }^{3}$ Similarly, the United Nations General Assembly in 2004 unanimously proclaimed the World Programme for Human Rights Education, which is structured in consecutive phases to advance the implementation of human rights education programs in all sectors. ${ }^{4}$ The current and second phase of the World Programme for Human Rights Education (2010-2014) focuses on human rights education in higher

\footnotetext{
${ }^{1}$ Vienna Declaration and Programme of Action (1993) Vienna. Available at http://www.ohchr.org/EN/ProfessionalInterest/Pages/Vienna.aspx (accessed November 10, 2014). See particularly paragraph 33, Section 1.

${ }^{2}$ Ibid.

${ }^{3}$ United Nations Decade for Human Rights Education (1995). United Nations General Assembly Resolution 49/184. New York; See also the Secretary-General Addendum to the Report of the United Nations High Commissioner for Human Rights on the Implementation of the Plan of Action for the United Nations Decade for Human Rights Education(1995) Issued Pursuant to General Assembly Resolution 50/177. New York. Available at http://daccess-ddsny.un.org/doc/UNDOC/GEN/N97/008/02/PDF/N9700802.pdf?OpenElement.

${ }^{4}$ World Programme for Human Rights Education (2004) United Nations General Assembly Resolution 59/113. Vienna.
} 
education and human rights training for teachers and educators, civil servants, law enforcement officials and military personnel at all levels. ${ }^{5}$

These international normative efforts underline the rights of every human being to human rights education, regardless of age, social class, educational level and any other circumstances. It also offers educators and policy makers a platform to reassess national human rights educational policies and priorities in the light of international standards. Bearing in mind that "human rights education and training is essential for the promotion of universal respect for and observance of all human rights and fundamental freedoms for all," it necessarily follows that human rights education is not only an entitlement of every human being, but also a necessity for responsible global citizenship. ${ }^{6}$ According to the United Nations High Commissioner for Human Rights, Dr. ZeidRa'ad Al Hussein, education must go beyond reading, writing and arithmetic, and ought to include skills and values that equip the citizenry to participate responsibly in their communities. He postulates that "education of any kind, if it is devoid of a strong universal human rights component, can be next to worthless when it should matter most: in crisis, when our world begins to unravel."7

The High Commissioner indicted the utility to humanity that Josef Mengele notorious for his role in the atrocities of the Auschwitz concentration camp had advanced degrees in medicine and anthropology, given that he was capable of committing the most inhuman crimes? He recounted that eight of the 15 people who planned the Holocaust at Wannsee in 1942 were doctorate degree holders, who shone academically, and yet were profoundly toxic to the world. He vilified their type of education which is bereft of the smallest iota of ethics, compassion and understanding when it mattered most. ${ }^{8}$

While advocating that schools need to nurture the curiosity and intelligence of the citizenry and recognizing that "knowledge of complex geometry, or molecular cell biology, or Cartesian philosophy - or thousands of other facets of the great kaleidoscope of human brilliance - can be a precious thing", Al Hussein posited that "when humanity topples on the

\footnotetext{
${ }^{5}$ Draft Plan of Action for the Second Phase of the World Programme for Human Rights Education (2010). Note by the United Nations High Commissioner for Human Rights. Geneva. Available at http://www.ohchr.org/EN/Issues/Education/Training/Pages/Programme.aspx.

${ }^{6}$ United Nations Declaration on Human Rights Education and Training (2014). Available at http://www.hrea.org/index.php?doc_id=1808. Geneva

${ }^{7}$ Z. Al Hussein, United Nations High Commissioner for Human Rights (2015), keynote speech on Conference on "Education for Peace". Available at http://www.ohchr.org/EN/NewsEvents/Pages/DisplayNews.aspx?NewsID=15482\&LangID=E. ${ }^{8}$ Ibid.
} 
cusp of real and vicious self-destruction, humanity does not necessarily need people who are smart, but people who are kind and with Ph.D.-level compassion". "People who feel joy, and generosity, and love, and who have fully integrated the values that are essential to life in freedom and dignity. We need people with a strong moral compass.” For a model education, Al Hussein proposes that:

Before every child on this planet turns 9 , he or she should acquire a foundational understanding of human rights. They should learn and experience the fundamental human rights values of respect, equality and justice. From the earliest age, human rights education should be infused throughout the program of every school—in curricula and textbooks, policies, the training of teaching personnel, pedagogical methods and the overall learning environment. Every child should be able to grasp that this recognition of blurred and cross-cutting identities - of the wonderful diversity of individuals and cultures within our shared membership of humanity - is a source of tremendous enrichment. Children are fully able to grasp the implications of human rights. And they are able, too, to understand the power that human rights principles bestows on them.

There is no gainsaying the fact that human rights education constitutes an essential contribution to the long-term prevention of human rights abuses and represents an important investment in the endeavor to achieve a just society in which all human rights of all persons are valued and respected. The Universal Declaration of Human Rights underlines the importance of human rights education in Article 26 and stipulates that "education shall be directed to the full development of the human personality and to the strengthening of respect for human rights and fundamental freedoms.” Also, member states of the United Nations have affirmed severally their unequivocal faith in the centrality of human rights education as the sustainable strategy for "the prevention of human rights violations and conflicts; for the promotion of equality and sustainable development; and to enhance people's participation in decision-making processes."9

In line with this premise, the unprecedented initiative of introducing human rights as first year common core course for all undergraduate students of pilot universities in Kenya is part of the implementation of the second phase of the World Programme on Human Rights Education and within the broader context of the United Nations Human Rights Council Resolution on the World Programme for Human Rights Education. It is also deliberately an effort to ensure that "children can learn that no human being

\footnotetext{
${ }^{9}$ Z. Al Hussein, United Nations High Commissioner for Human Rights (2015), keynote speech on Conference on "Education for Peace". Available at http://www.ohchr.org/EN/NewsEvents/Pages/DisplayNews.aspx?NewsID=15482\&LangID=E.
} 
can properly be defined by a single point of reference: not nationality, not ideology or religion"

Children need to learn what bigotry and chauvinism are, and the evil they can produce. They need to learn that blind obedience can be exploited by authority figures for wicked ends. They should also learn that they are not exceptional because of where they were born, how they look, what passport they carry, or the social class, caste or creed of their parents; they should learn that no-one is intrinsically superior to her or his fellow human beings. Children can learn to recognize their own biases, and correct them. They can learn to redirect their own aggressive impulses and use nonviolent means to resolve disputes. They can learn to be inspired by the courage of the pacifiers and by those who assist, not those who destroy. They can be guided by human rights education to make informed choices in life, to approach situations with critical and independent thought, and to empathize with other points of view. Sadly, they must learn that the Zeppelin Field, the shadow of Buchenwald, the glint of the machete and the horror of life today in Syria, Iraq, South Sudan, Central African Republic and elsewhere-wherever we live, they are never that far away. These lessons are surely as fundamental to life on Earth as advanced calculus. ${ }^{10}$

As elucidated by Amartya Sen, since every human being has many identities, related to gender, nationality, language, location, class, religion, occupation, political beliefs and personal inclinations, the "best hope for peace in the world lies in the simple but far-reaching recognition that we all have many different associations and affiliations; we are not rigidly divided by a single categorization of hardened groups which confront each other."11

\section{KENYA EXPERIENCE}

The unparalleled innovation of introducing human rights as a first year common core course for all undergraduate students of pilot universities in Kenya is not a standalone initiative. It is amongst other things predicated on the fact that human rights has been elevated as one of the national values and principles of governance that binds all states organs, state officers, public officers and all persons in the interpretation of the constitution, and in the implementation of public policy in Kenya. ${ }^{12}$ With a human rights-based Constitution adopted by the government and people of Kenya in 2010, that

\footnotetext{
${ }^{10}$ Z. Al Hussein, United Nations High Commissioner for Human Rights (2015), keynote speech on Conference on "Education for Peace". Available at http://www.ohchr.org/EN/NewsEvents/Pages/DisplayNews.aspx?NewsID=15482\&LangID=E.

${ }^{11}$ S. AMARTYA, IDENTITY AND VIOLENCE; THE ILLUSION OF DESTINY (New York 2006)

${ }^{12}$ Article 10, Constitution of Kenya (2010). National Values and Principles of Governance.
} 
comprehensively recognizes and offers protection for civil and political rights as well as economic, social and cultural rights, introducing human rights as a first year common core course for all undergraduate students of the pilot universities takes cognizance of the fact that universities are fountains of knowledge and best suited as avenues for valued transformation of society.

Introducing human rights as a common core and interdisciplinary course in this regard is also a strategic effort that recognizes the fact that the next crop of leaders and persons with significant responsibilities within the society would largely if not entirely constitute persons currently undergoing university education. Empowering these people early ensures that the country has a chance of being run by leaders and populace who are sensitive and advocates of human rights. On the other hand, it provides an excellent platform to build the capacity of leaders of tomorrow to engage with human rights from a multi-sectoral, multi-dimensional, inter-disciplinary perspective, and most importantly as a cardinal pillar of good governance and a just society.

The enjoyment of all human rights by all as envisaged in the Constitution can only be realized when every educator becomes a human rights defender and every educational institution transforms into a zone of tolerance and dignity. Human rights can also be realized through an informed citizenry empowered individually and collectively to make continued demand for the promotion and protection of all human rights. For this level of awareness and capacity to be developed, the Human Rights Education Initiative by the Office of the High Commissioner for Human Rights is paramount in Kenya, and as well as in other countries. ${ }^{13}$

Globally, whilst existing resourcefulness have facilitated the incorporation of human rights in higher education as either a master's degree programme or as an elective course within the bachelor's degree programmes, minimal success has been made in the introduction of human rights as a first year common core course to be undertaken by all undergraduate students irrespective of department or faculty. As such, existing human rights education programmes are selective, restrictive,

\footnotetext{
${ }^{13}$ The Office of the High Commissioner for Human Rights coordinates the World Programme for Human Rights Education and the United Nations education and public information programmes in the field of human rights. It works to promote human rights education by supporting national and local capacities for human rights education in the context of its technical cooperation programme and through the Assisting Communities Together (ACT) Project, which provides financial assistance to grass-roots initiatives. It develops selected human rights education and training materials; resource tools, such as a database on human rights education and training, a resource collection on human rights education and training.
} 
ostensibly accessible to a few, and lack the multidisciplinary element which is necessary for a holistic understanding and appreciation of human rights by all.

On the understanding that a multidisciplinary study of human rights for all undergraduate students has the potential to empower students as future human rights promoters and protectors, the United Nations Office of the High Commissioner for Human Rights has collaborated with three pilot universities in Kenya to introduce human rights as a first year-course for all undergraduate students. ${ }^{14}$ The endeavor in its first year and pilot phase is targeting a student population of 50,000.

\section{SCOPE AND METHODOLOGY}

The course is multi-disciplinary in nature and encompasses introductory topics including historical development of human rights, overview of regional and international human rights instruments and mechanisms, national human rights institutions and enforcement mechanisms, etc. The general objective of the course is to equip learners with the basic knowledge of human rights, particularly in the context of Kenya. It equally seeks to develop knowledge and understanding of the international legal and reporting frameworks before taking an incisive look at the Kenyan human rights framework. While providing an overview of the justice framework of Kenya, the course highlights the specific needs of vulnerable populations, such as women, children, and older persons, persons with disabilities, internally displaced persons and marginalized communities.

As a one semester course which shall run for a minimum of 15 weeks disaggregated into forty five lecture hours, the methods of instruction consists of lectures, in lecture discussions, class presentations, case studies, student-teacher consultations, supervised independent study and coursework.

The Office of the High Commissioner for Human Rights adopted a four-step approach in actualizing this initiative. The first step was to embark on consultation with relevant stakeholders for their buy-in. It involved dialoging with Deans of Studies, Academic Registrars, Vice Chancellors and ultimately addressing Senate Committees of the respective universities.

\footnotetext{
${ }^{14}$ Universities in Kenya operate and develop their discipline and course content independently, they are however supervised and their quality assured by the Commission for Higher Education established in 1985 by an Act of Parliament. From 1964 to 1984 Kenya had only one university with an enrolment of 7,624 students. The number of universities increased to six from 1984 to 1990, with a corresponding increase in student enrollment to 11,110 in 1990/1991. Currently there are over thirty universities with an approximate enrollment of 145,000 students, of which $85 \%$ are enrolled in the seven public universities.
} 
It was also a platform to discuss with concerned actors the methodology and sequencing of the proposed initiative, sample interested institutions of learning and identify pilot universities.

The second step was to engage with focal-groups in the pilot universities in the preparation of a course description, course justification, course requirements, course delivery strategy, course learning outcomes and course outline. After the development of the syllabus by the focal-group, with the technical assistance from the Office of the High Commissioner for Human Rights, the final product was subjected to a multi-stakeholders validation process with the participation of representatives from academia, the judiciary, lawyers, civil society organization, and public institutions involved in the promotion and protection of human rights.

The third step involved the nomination of lectures drawn from across, departments, colleges and faculties of the pilot universities who will teach the course. Having identified the team of lectures for the course and bearing in mind that they have uneven understanding and knowledge of human rights, they were enrolled in a series of capacity building courses on human rights that culminated in pedagogical trainings on human rights. The final step was to officially launch the course in the pilot universities and commencement of the teaching.

The first university in Kenya to embark on this initiative was the Laikipia University, a public institution situated in Kenya's Rift Valley Province. Following a series of consultations and consequent senate approval, human rights as a first year common core course for all undergraduate students was officially launched in December 2013. The University has seen the first batch of 10,000 students undertake the course as well as sit for exams. The second university to approve the introduction of human rights as a first year common core course for all undergraduate students is Egerton University followed by the University of Nairobi currently at an advanced stage in the process. A framework for the introduction of human rights as a first year common core course for all undergraduate students of the University of Nairobi has been perfected through a memorandum of understanding with between the university and the Office of the High Commissioner for Human Rights.

\section{CONCLUSION}

Strides made in the introduction of human rights as a first year common core course for all undergraduate students in pilot universities in Kenya is undoubtedly an innovative step in inter alia nurturing students to 
cultivate the capacities to make moral choices, take principled positions on issues, incline to democratic and civil actions and develop moral and intellectual integrity that transcends personal and parochial interests.

This initiative is expected to translate into a genuine cooperation that will in the long term enable students develop a deeper understanding of human rights and be able to apply its universal principles in their lives within and outside the university. It will also create well-informed citizenry conversant with the inalienability of human dignity and the need to create demand and supply side of accountability, transparency and peaceful coexistence.

The Office of the High Commissioner for Human Rights commends the pilot universities in Kenya for strategically envisioning the capacity needs of the leaders of tomorrow and for proactively pioneering a collaboration that will align the skills of its students to the demands of an evolving world where human rights is an integral and inseparable component of governance. The Office of the High Commissioner for Human Rights envisions that this innovative and unprecedented initiative will be replicated in other regions of the world. 